\title{
Selling the Cryptosphere in China
}

\begin{abstract}
China, one of the world's most clandestine states, is currently engaged in moves to make state secrecy a matter of public policy, even inaugurating a "National Security Education Day” in 2016. This article explores some recent campaigns about spycatching to show how the state is using crowdsourcing, content marketing, and prosumerist gambits to sell an emergent social space of civic duty that I term the cryptosphere. Inciting civic participation is a particularly deft tool for propaganda work of this kind, which pivots on performative ideology. The ostensible purpose of these campaigns is to enlist the Chinese people in the securitization of the state; but in practice this is a highly disingenuous move given that the realm of the classified in China is so vast that "keeping secrets" can only be perfunctory for almost all of its citizens. So far, commentators outside China have either been amused by the state's new forays into infographics and mash-up videos, or critical of their xenophobic messaging. But the state's apparently light-hearted drive to remind the Chinese people of the need to track spies is only peripherally about foreigners. It is occurring at a time when the government is also trialling a potential algorithmic grab on its own citizens' personal data via the social credit system; operating a CCTV surveillance regime of more than one million cameras; and conducting mandatory biometric profiling in Xinjiang, using DNA, blood types, iris scans, and fingerprints. These policies, I argue, constitute the exoskeleton of the cryptosphere. But this new sphere also needs its soft padding. Propaganda campaigns which school subjects on how to perform the role of loyal "informants" - at the very moment that their own information is actually being expropriated at speed by the state - are providing just this kind of thought work cushion.
\end{abstract}

A basic search on Baidu, China's largest search engine, for the National Bureau for the Protection of State Secrecy (guojia baomiju) turns up an image of an imposing white-colonnaded building, its rows of opaque windows reaching out beyond the borders of the frame, its address not immediately discoverable. This physical presence of the Bureau conjures, almost irresistibly, a vision of sealed vaults and encryption keys, behind which might presumably lie top-secret information about such matters as how SARS started, the number of millions who died in the Great Famine of 1959-62, or the exact contents of Mao’s personal lockbox. ${ }^{1}$ Click further on Baidu, via its “Baidu Knows” function (the platform’s collective intelligence Q\&A service), and this concrete vision recedes slightly into the distance. The question "What, may I ask, is the physical address of the National Bureau for the Protection of 
State Secrecy?” throws up comments such as “That’s a secret!”, "If I told you that, it wouldn’t be secret anymore, would it?”, and “there are dozens of them!”. This latter point is, at least, more instructive than facetious, since there are indeed municipal and provincial bureaux of secrecy all over China, from Inner Mongolia to Yunnan, just as state secrets themselves are subject to tiered classification: “top secret” (juemi), "highly secret" (jimi), and mimi (secret). The location of secrecy seems, in this sense, to be both everywhere and nowhere: secrets and their bureaucratic management cast a ubiquitous web, but presumably the hard substance of what they hide can only thin out in tandem with this secretion. Or, to put it another way, how secret are the secrets that all these bureaux hide?

Unsurprisingly, the legal ambit of secrecy in China is as broad as it is fuzzy. The "Law of the People’s Republic of China on Guarding State Secrets" (Zhonghua Renmin Gongheguo baoshou guojia mimi fa), promulgated in 1988, is so amorphous in its definitions that it is hard to imagine public actions that lie categorically outside it. $^{2}$ A follow-up law, “Measures for Implementing the Law of the People’s Republic of China on Guarding State Secrets” (Zhonghua Renmin Gongheguo baomi guojia mimifa shishi banfa 1998) extends the scope still further by permitting retroactive classification of information whose disclosure might later prove harmful to the state. An amendment to the main law, passed in 2010, clarifies certain procedures, but nevertheless retains this fundamental opacity over the precise definition of the state secret, via catch-all, quasi-syllogistic phrasings such as "all state affairs not yet decided upon”, "all other state affairs that must be kept secret”, and "other matters that are classified as state secrets by the National State Secrets Bureau”. ${ }^{3}$ In practice, this means a stranglehold over all kinds of intelligence: as the NGO Human Rights in China (HRIC) puts it, “the state secrets framework presents problems of over- 
classification, subjectivity and arbitrariness”, and sweeps “a vast universe of information into the state secrets net” (2013, p.1, 10) . Meanwhile, the “Interim Provisions on the Management of State Secrets” (Guojia mimi dingmi guanli zanxing guiding 2014), a law which aims in part to define which state organs have the power to classify information, actually makes it clear that many bodies within the Chinese party-state have the power to classify information as state secrets, including such bodies as the Supreme People's Court, the Academy of Sciences, the Academy of Social Sciences, the Chinese Red Cross, the All-China Federation of Trade Unions, the China Council for the Promotion of International Trade, and several other semiofficial organizations, such as top universities and state-owned enterprises (SOEs) (Finder 2014). State secrecy, in other words, is every cadre’s business.

A little-discussed, government-affiliated website - the virtual arm of the National Bureau, in fact - throws a sharper light on this point. China Secrecy Online (Zhongguo baomi zaixian), as it is called, features a homepage densely packed with content: news stories about state legislation on whistle-blowers; articles on topics such as information security, ancient Chinese theories of secrecy, and local developments in secrecy management; mini-biographies of homely-looking cadres from different bureaux branches; and a section on data-integrated management systems, encryption equipment, and other technology products. ${ }^{4}$ Further into the website can be found an online "secret bookstore" selling volumes on spy craft, Bletchley Park, and Edward Snowden, as well as digital issues of the site's flagship publication The Work of Protecting State Secrets (Baomi gongzuo); a section called “Secret Professional Knowledge Base”, with cadre case studies (“confessions of a leaker”), and keyword definitions (what does the "work of protecting secrets” mean?); and an online learning platform with webinars about the "propaganda of keeping 
secrets” (baomi xuanchuan), which includes a multi-media online course, workplace posters showing the right and wrong ways to shred confidential documents, and multiple choice quick quizzes. The format and content of this central website is mirrored quite closely in local versions, such as the online presence of the Shanghai Bureau of State Secrecy, which also contains clips from espionage movie classics (The 39 Steps, North by North West, Case No. 36) (figure 1), alongside faux-stern cartoons and anime, as shown in figures 2-4. Given their professionalized content, we might presume that the core audience for these websites is lower- and middle-ranking officials within China's extended national security apparatus. If so, the openness of the sites seems an anomaly: official policy about the practicalities of securitizing state secrets surely belongs on private networks, behind firewalls. Why are these pages browsable for ordinary Chinese netizens, let alone users overseas?

In this paper, I argue that China Secrecy Online is emblematic of a broader governmental push to propagandize the notion that state secrecy is, in fact, every citizen’s business. I begin by noting the well-established idea of China as a hard cryptocracy, a state that is ruled by the doctrine of secrecy, in which power is exercised by éminences grises in the shadowy spaces of Zhongnanhai, the leadership compound in Beijing in which power has been brokered under CCP rule. More recently, though, the remit of secret-keeping has been extended via a new playbook of propaganda strategies. These seek to create an emergent social space that I term the cryptosphere, in which ordinary citizens are drilled in the duties of securitizing Chinese society from the threats of foreign spies and local traitors. In keeping with a now-established shift away from harder propaganda methods of the past, the methods of thought work deployed to construct this sphere are new-media-based and consumer-friendly, and turn on techniques of content marketing, crowdsourcing, and 
prosumerism. I look at some recent campaigns about state secrecy - a counterespionage cartoon poster promotion in Beijing ahead of the first National Security Education Day in 2016, a crowdsourced attempt at spycatching conducted via video animation in 2017, and a cartoon competition run during 2016 and 2017 by the website of the Guangzhou Bureau of State Secrecy to promote the "Law on State Secrecy" - to show how the state is using new-media tools to market the cryptosphere as a space of civic duty and belonging.

Inciting participation, I suggest here, is a particularly deft tool for propaganda work of this kind. The ostensible purpose of these campaigns is to enlist the Chinese people in the securitization of the state; but in practice this is a highly disingenuous move given that the realm of the classified in China is so vast that "keeping secrets" can only be perfunctory for almost all of its citizens. So far, media and academic commentators on China's security apparatus seem mostly amused by the state's new forays into infographics and mash-up videos. ${ }^{5}$ Certainly, some of these propaganda productions come over as kitschy, even inept. Often, moreover, it’s a villainous flame-haired foreigner who scene-steals in these stories - which has led to predictable griping about state-sponsored xenophobia in Anglophone media outlets. ${ }^{6}$ But the CCP's new drive to remind the Chinese people of their secret-keeping and spycatching duties is only peripherally about foreigners. It is occurring, by no coincidence whatsoever, at a time when the state is also trialling a vast algorithmic grab on its own citizens' personal data via a social credit system that encourages selfmonitoring; ${ }^{7}$ operating a CCTV surveillance regime of more than two million cameras; ${ }^{8}$ and conducting mandatory biometric profiling in Xinjiang, using DNA, blood types, iris scans, and fingerprints. These policies, I suggest, constitute the exoskeleton of the cryptosphere. They are the hard levers engineering an 
informational transfer of extraordinary proportions from people to state in contemporary China. But this new sphere also needs its soft padding - so in this sense, we might argue that these new propaganda campaigns are simply a cutesy thought work cushion designed to get people comfortable with the new order, to naturalize a hard regime of surveillance and control. I argue, though, that these campaigns aim for more. Rooted in the idea of training citizens in how to be "informants" - at the very moment that their own information is actually being expropriated at speed by the state - China's new-media thought work also seeks to incite performances of loyalty from its citizens. And as Žižek points out, going through the motions, even when we do so in lackluster, half-hearted ways, ultimately works to concretize belief in the actions which we perform.

\section{Cryptocratic China}

For some years now, theorists of secrecy have been issuing warnings about the imminent expiration of the exposé - and by extension secrecy itself as once we knew it - as a functioning construct in public life (Baudrillard 1999, p. 163; Bratich 2007, p. 42-58; Nuttall and Mbembe 2015, p. 323; Birchall 2016, p. 152-163). Well before the Trumpian days of "alternative facts”, the idea that truth could take on power by unmasking its cover-ups and covert ops was already floundering. As exposés from Watergate through WikiLeaks to the Panama Papers have failed to take down very much at all, secrecy has morphed into a form that Debord identified as "generalized": an entity which advertises itself and its doings as a play of power, and stands as the “most vital component” of the society of the spectacle (1998, p. 12). Or as Slavoj Žižek put it of Wikileaks, "the only surprising thing about the ... revelations is that they contain no surprises. The real disturbance was at the level of appearances: we can no longer pretend we don’t know what everyone knows we know” (2011, p. 9). 
These arguments do not, of course, invalidate disclosure or whistleblowing as political practices. Yet as the life cycle of newsworthy revelations shortens, and exposé fatigue sets in, state secrecy inevitably acquires a character both more showy and more untouchable, not least since the secrets that citizens get to find out about are unlikely to be the most important ones. In this sense, we might see the secrecy websites just mentioned as a local variation of secrecy-as-spectacle, rendered even more blatant for the simple reason that the state and its agents have still less need to hide in cryptocratic China. Yet the sites and their visuals - particularly the bookstore, cartoons, film clips and posters - ultimately produce a rather different impact from spectacular secrecy as its theorists in Western democracies have described it.

This is not to suggest for a moment that China does not practice secrecy as sinister spectacle to the hilt, as already suggested. An egregious example in recent years is the practice of forced "disappearance”, now known as "Residential Surveillance at a Designated Location” (RSDL). Human rights activist Teng Biao describes this secret detention system as follows:

After I was kidnapped, I was detained in secret for 70 days. I was told I was being placed under Residential Surveillance. No one ever told me their name, department, or position. Nobody ever showed me a work permit, search warrant, or any legal documents ... During this time, I was beaten, deprived of sleep, forced to maintain stress positions, forced to wear handcuffs for 24 hours a day for 36 days, threatened, abused, forced to write a confession, and otherwise ill-treated. Even now, years later, it is hard to put it into words (Caster 2017, p. 12).

In one sense, RSDL is the epitome of a shadowy, below-the-radar, and discreetly punitive practice, since few in China - let alone anywhere else - know where these black jails are, who runs them, how they operate. Yet at the same time, disappearance is an established tactic for states which like to flaunt secrecy as spectacle, for the simple reason that extrajuridical measures such as these churn rumour, lore, and fear far more effectively than straightforward trial and incarceration. What the United 
Nations’ Committee on Enforced Disappearances refers to as the "refusal to acknowledge the abduction (of persons) or the concealment of their fate or whereabouts" is a move which turns the missing person into a disembodiment of state power, visible - spectacular - precisely because of her or his invisibility. ${ }^{9}$ As such people are suctioned out of the fabric of the social, they testify to both the brute force of the state and to the brazenness with which it deploys strategies which are supposed to be occult.

This image of China as “The People’s Republic of the Disappeared” - a cryptocracy of untold muscular and minatory powers - is now a well-established one. Most particularly since the rise of Xi Jinping, Western media accounts about China's hidden overseas aid empire, its secret bitcoin mines, its covert nuclear programme, its use of cross-border extraordinary rendition, even its espionage tactics against global underwear giant Victoria's Secret, have spelled out a dark subtext to surging Chinese power. ${ }^{10}$ Black ops et al. "prove", in short, that EuroAmerica is right to fear China and to militate for its containment. The predations of state secrecy in China against its own subjects constitute a parallel theme: the policies mentioned in the introduction to this paper, the exact number of clandestine executions China carries out, the vast sums that high officials have secreted in offshore bank accounts, the undercover “clean-ups” the state carries out against some of its most vulnerable citizens. In cases such as these, government and grass-roots actors are starkly polarized: the state acts spectacularly/covertly against its subjects, and secrecy is very much official business, by which I mean the business of officialdom. This focus on China as a cryptocracy - a state which governs via secrecy and whose governance is secretive - is reasonable enough. Yet at the same time, it draws attention away from the fact that China is also an emergent or would-be cryptosphere, a society which is being encouraged to get 
comfortable and at ease with state secrecy as an ambient quantity, to be policed and protected by one and all.

\section{Naming the cryptosphere}

To call China’s increasingly securitized social world a cryptosphere is to invite comparison with other accounts of how states elsewhere have sought to apply and administer secrecy as a form of governmentality. To an extent, the functions of the cryptosphere go right back to Debord, who noted that "almost no one sees secrecy in its inaccessible purity ... Everyone accepts that there are inevitably little areas of secrecy reserved for specialists; as regards things in general, many believe they are in on the secret" (1998, p. 60-1). In a situation of "generalized secrecy”, the latter forsakes its sacred status and, as it gets bigger and bolder, is steadily re-tooled as a means of co-optive, even disingenuous control. China's cryptosphere has more specific resonances with Joseph Masco’s analysis of how both the Cold War and the post-9/11 counter-terrorist US state "transformed America into a new kind of secret society, one in which state power rests to an unprecedented degree precisely on the ability of officials to manage the public/secret divide through the mobilization of threat” (2010, p. 433). Under this regime of the clandestine, "official secrecy is a social technology, a means of internally regulating and militarizing American society” (p. 443). For sure, China's cryptosphere is a social space placed on a showily martial footing, as evidenced by publicity shots from the 2019 "National Security Education Day”, which feature elementary school children being instructed in how to use antiassault equipment. But the Chinese cryptosphere also diverges from Masco’s formulation of the secret society. In particular, the state deploys the notion of threat far more tepidly, and is focussed instead on reaching out and co-opting the citizenry into performative and fundamentally phoney labours of secret-keeping. 
To the extent that this process of co-option has an expressly culturalist dimension - via its use of mash-up videos and cutesy cartoons - China's emergent cryptosphere may also be a partial peer for what Timothy Melley dubs the American "covert sphere”: "an array of discursive forms and cultural institutions through which the public can 'discuss' or, more exactly, fantasize the clandestine dimension of the state” (2012, p. 5). ${ }^{11}$ For Melley again, though, there are dividing lines - however permeable - between the covert sphere and what he terms the "covert sector”, the state institutions in which secrecy is officially sequestered and yet from which it routinely leaks, or “secretes”, into society. China’s cryptosphere is, by contrast, rhetorically unbordered, at the same time as the perimeter between the cryptocracy and the cryptosphere is far more stringently patrolled. Everyone is a trainee secretkeeper, and so cultural products about the clandestine are more pedagogical than fantastist. In this latter sense, the cryptosphere arguably shares greater space with what Bratich calls “popular occulture”: namely, espionage as hobby, and "the becoming-spy of citizens” within larger projects of so-called militainment (2014, p. 12). Yet the "citizen spy" of this formulation is essentially an echt, rather than ersatz, identity: she really wants to learn some spycraft. China’s cryptosphere, as will become clear, is constituted by a citizenry who for the most part are neither genuinely learning about undercover ops nor imbibing their lessons about national security with any great gusto. As such, the cryptosphere and its folk form a kind of inverse parallel to the US Homeland Security policies of citizen recruitment, which sought to outsource responsibilities for managing security onto the broader populace via a "doit-yourself” model (Hay and Andrejevic 2006, p. 338). ${ }^{12}$ The difference here is that the real labor of securitizing the realm has been commandeered by the Chinese state as its own robust and untouchable domain. 
In short, the Chinese cryptosphere is a performative arena, and the show it puts on is ideological in a Žižekian sense. For Žižek, ideology is often deeply cynical; it has no need for zeal, false consciousness, let alone true conviction as the latter is commonly construed. Žižek argues that belief is, in fact, “radically exterior, embodied in the practical, effective procedure of people” (1994, p. 317) - which is another way of saying that going through the motions, acting it out, is a performance that concretizes our beliefs even if these are not shored up by any real mental conviction. We believe what we do, rather than do what we believe. As Žižek puts it

It is similar to Tibetan prayer wheels: you write a prayer on a piece of paper, put the rolled paper into a wheel, and turn it automatically, without thinking ... The beauty of it all is that in my psychological interiority I can think whatever I want, I can yield to the most dirty and obscene fantasies, and it does not matter because - to use a good old Stalinist expression - whatever I am thinking, objectively I am praying (p. 317).

China's incipient cryptosphere is inciting from its citizens an annual set of performances - prayer-wheeling - about the collective urgency of secret-keeping, spy-catching, and securitizing the realm which harnesses precisely this kind of ideological power. While the exoskeleton of surveillance, social credit, and biometric rule grows tougher, performative secret-keeping and sham spy-catching - acting it out - is a political practice designed to materialize popular belief that national security (rather than raging social inequality, let alone data protection) is China’s collective top priority. In this sense, I make a case here for the singularity of China's project for secrecy-as-social-management in the big data epoch. Superficially, these plans consult a well-thumbed playbook, from the secretization of society to the "citizen spy". But the Žižekian dimension - the use of performance to concretize faith in a civic relationship with state secrecy that people may not believe in at all - is arguably a move that China is honing in specifically localized ways at present. To make this case is not to pander to the Sinophobes who plead for the reasonableness of "China 
containment”, but rather to scope out the implications of this security agenda during an era when China has become less a “destination nation” than an increasingly active exporter of political practices. And the ideological power which this harnesses is crucially enhanced, as I describe next, by the state’s recourse to revamped ploys of propaganda.

\section{Soft-selling the clandestine}

In a world where so much of China’s secret behaviour remains precisely and impenetrably that - secret - the government websites I mentioned above offer oddly open portals on how the state seeks to manage intensive information control and nurture the growth of this cryptosphere. Indeed, there is a choice irony not only in the fact that one of the planet's most covert states runs a website called China Secrecy Online, but also that these sites do actually “leak” revelations: not about bitcoin mines or Mao’s lockbox, of course, but about state secrecy as an emerging social method in China. Under the long shadow of so-called "Pekingology" - the venerable craft of the China watcher who had only scant hard evidence to hand, and so tried to read the mystic runes of Politburo behaviour instead - contemporary studies of China's secret doings often proceed on the premise that researchers will have to develop undercover strategies themselves, as shown by the investigation carried out by AidData, a research lab based at the College of William and Mary, into overseas Chinese aid. ${ }^{13}$ By contrast, the websites of China's state secrecy bureaux testify to the strangely paradoxical fact that sometimes the easiest means of access to secret intentions, or intentions about secrecy, is through the front door.

At base, these websites take their cues from China's constitution, article 53 of which states that all Chinese citizens must “protect state secrets” (baohu guojia mimi), and from article 398 of China’s Criminal Law, which makes it an offense to reveal 
state secrets even if the disclosure is inadvertent. ${ }^{14}$ These acts of law enshrine the principle that state secrecy is not just the work of the multiple governmental bodies listed above, but a public duty - even when the public knows not what the secret is. In this sense, the tone and substance of the websites constitute a pedagogical push, a soft-pedalled educational campaign which instructs the Chinese people in how to be appropriately protective of the secrets that swirl, out of sight, around them. This point crystallizes in article 7 of "The Regulation on the Implementation of the Law of the People’s Republic of China on Guarding State Secrets” (Zhonghua Renmin Gongheguo baoshou guojia mimifa shishi tiaoli 2014), which states that "Secrecy administrative departments at all levels shall organize publicity and education on secrecy on an ongoing basis”. ${ }^{15}$ State secrecy-as-education crystallized in the wake of this regulation when China marked its inaugural "National Security Education Day" (Quanmin guojia anquan jiaoyu ri) on April 15, 2016, with ceremonial pomp and promotional flutter. Cumulatively, these moves make it clear that state secrecy is, in fact, everyone’s business in China, a collective enterprise which bureaucrats are expected to steer and shepherd, but which encompasses the entire populace in its orbit. The question then becomes: how are ordinary citizens to be instructed in keeping state secrets which these same citizens, by dint of their very ordinariness, know nothing about? Or cutting closer to the chase, if ordinary citizens have no state secrets to keep, what is the purpose of legislating so inclusively for confidentiality?

China Secrecy Online and the many other websites maintained by municipal and provincial bureaux of secrecy in all parts of China throw some direct light on these queries. To browse these online spaces, with their news stories, merchandise, webinars, and quizzes, is to be oddly but insistently reminded of the world of content marketing. Omnipresent as an advertising strategy on the web in recent years, content 
marketing pivots on the creating and sharing of online material, but it holds back from promoting a brand outright, preferring to pique interest in its products or services by informational means. The core aims of the content marketer are to grow a user base, network those users into a web community, and build the credibility and reputation of a brand using such tools as blog posts, eBooks, videos, webinars, quizzes, competitions, how-to guides, infographics, and interviews. Essentially, content marketing works by generating and curating content that consumers will actively seek out - pull versus standard propagandastic push - which is why it is now commonplace to suggest that its tremendous rise is turning traditional businesses into media publishing companies. Or as Joe Pulizzi puts it, it is all about "the idea that storytelling is key to attract and retain customers ... (and) the creation of valuable, relevant and compelling content by the brand itself ... (is) used to generate positive behaviour from a customer or prospect of the brand” (2012, p. 116).

To an extent, China's secrecy websites indicate that government departments are absorbing the lessons of this shift. Indeed, as noted above, China Secrecy Online is well understood to be the media publishing arm of the National Bureau for the Protection of State Secrecy. Rather than ordering people to keep state secrets which they know nothing about, the site effectively seeks to turn this civic duty into a role to be content-marketed - to be made an object of proto-consumerist interest and brand loyalty - via a textbook deployment of the tools listed above. The degree to which the website succeeds is, of course, another matter, and one very hard to track empirically. Visitor counters are not displayed, nor is information about page views, and searches for the site on social media in China turn up few results. Certainly, the almost outrageous paradox of attempting to turn state secrecy into a brand occasionally slips up, as overseas visitors to China Secrecy Online discover when they try to access 
certain content and are repeatedly re-routed to an error page; or when specific pages on the local Shanghai website will only load when accessed via an anonymous browser. Yet as a network of state-run platforms, the secrecy sites make it clear that beefed-up displays, such as the violently disappeared human rights activists, are only one part of what the clandestine strategy means and does in China, and that secrecy as a state ideology is also taking softer, sellable form. Much more to the point, the sites are only one small part of a much larger mission to promote the duties of the civicminded secret-keeper.

Ultimately, though, what we witness here are practices of propaganda coming full circle. After all, thought work has always been narratively driven and contentheavy, even when it favoured more traditional media - and as such, it is the content marketers who borrowed several core strategies from the cultural apparatchiks in the propaganda bureau, rather than the other way around. Indeed, the emergence of content marketing ploys here is simply a component part of the concerted marketization of propaganda that has been underway in China for the last two decades, in a set of moves that echo so-called "convergence culture" everywhere. Taking Andrew Wernick’s notion of promotional culture - "the intensive and extensive development of the market as an organizing principle of social life” (1991, p. viii) - deeply and diffusely into the propaganda domain, thought work has long had a mercantilist tinge in China. As Anne-Marie Brady has noted

From the early 1990s, selective concepts from the fields of mass communication, public relations, advertising, social psychology, and other methodologies and theories of modern mass persuasion were introduced into China's propaganda system (2009, p. 67).

And just as folk and popular culture served as a core vessel for propaganda during the Maoist period, so too have "the cultural forms utilized ... been updated to match contemporary trends” (Brady 2009, p. 74) - hence the increased use of new media, 
from mash-up videos to infomercials, within projects that are now becoming ever more prosumerist. In this sense, the propaganda products about secrecy I discuss here share a kinship with what Maria Repnikova and Kecheng Fang call “authoritarian participatory persuasion 2.0", in which "the targets of propaganda are made into active collaborators in the process of recreating pro-party discourses online” (Repnikova and Fang 2018, p. 765). The state invites "bottom-up participation in the form of sharing and creating content on official platforms", and incites "participation in governance agenda of the state via crowdsourcing and other initiatives” (p. 771).

The argument most commonly made about China’s new-style participatory thought work is that the novelty factor and interactive features of these media forms make the propaganda they tout more appealing. Via this technique, netizens are “carefully cajoled into the social orbit” (p. 772), as they are beguiled by winsome digital formats into feeling citizenly as they help the state out with tasks such as locating lost children and sharing tips on how to cope in a minor earthquake. Up to a point, this point seems indisputable, particularly when ideological work today is constrasted with the hard-core and sometimes preposterous "groupthink" campaigns of Maoist times. So-called “selling cuteness”, or mai meng, is everywhere now in state propaganda, and for solid promotional reasons. But as a concerted ideological strategy, the moves to promote state secrecy as public duty also exercise a different kind of leverage within propaganda settings. This latter leverage has little to do with the power to persuade. As Hannah Arendt noted, the "the true goal of totalitarian propaganda is not persuasion, but organization of the polity” (1973, p. 361). She continues by noting that "what convinces masses are not facts, and not even invented facts, but only the consistency of the system of which they are presumably part” (1973, p. 351). 
For most scholars of China's new participatory propaganda, though, the new thought work is principally about mass persuasion: they argue that PR, polling, entertainment ploys, and the like possess proven capacity to manufacture popular consent and thus calcify social control. ${ }^{16}$ This claim no doubt holds true for the lost children and earthquake tips just mentioned. But marketing state secrecy is a far tougher sell. This is because any "eyes wide open” citizen of contemporary China knows full well that secret-keeping, intelligence-gathering, and spy-catching will never really be their business. Indeed, it is fanciful puff to suggest that much security savvy belongs to the people at a time when wraparound surveillance, panopticon policies, biometric profiling, social credit, and real-name registration on the internet are delivering to the state more hard and crunchable data about its citizens, and its enemies, than ever before. This is not to dispute that China under the CCP has a long track record of using informants to assist it in the work of flushing out counterrevolutionaries, saboteurs, and other opponents of the party. These ranged from lowlevel neighbourhood moles or snitches, known as shehui ermu (social eyes and ears), to far more skilled assets, called teqing renyuan, who formed a sophisticated apparatus of citizen-agents engaged in tasks of information-gathering, surveillance and control. ${ }^{17}$ But as Michael Schoenhals has shown, these earlier CCP efforts to enforce public security via informants were fundamentally domestic in orientation: they took place "on the home turf” with local targets in mind. Perhaps more importantly, the entire modus operandi of the system was predicated on an "us" and "them”, on the notion that only some citizens of the People’s Republic could be trusted with the vital business of securitizing the state.

Now, though, it has become the civic duty of all to catch the foreign spies who are the enemies of everyone - and therein lies the essence of the Žižekian ideological 
ploy. Indeed, although some local governments may now be tactically resuscitating some of the community-based policing methods of China's recent and dynastic past, ${ }^{18}$ the fact is that the state has far less need than ever for amateur assistance in its increasingly sophisticated and thoroughgoing policies of social control. It might be argued, in fact, that its arsenal here is more powerfully stocked than that of any other government in human history. At a time when the state is more than strong enough to stand alone in securitizing China against external threats - as indicated all too clearly by the grand info heist it is perpetrating on its own people right now - the new-media propaganda campaigns I discuss in the next section are only superficially about the "persuasion” part of Repnikova and Fang's model for propaganda in the age of Web 2.0. Far more pertinent is the "participatory" dimension, for the simple reason that new-media propaganda, with its crowdsourcing, content marketing, interactivity, and prosumer gambits, is vastly more adept than the booming loudspeakers and model operas of yore at getting people to "act it out”. This revamped thought work is neatly tooled to concretize belief in the inherently implausible.

\section{Crafting the cryptosphere}

The run-up to the first “National Security Education Day” in 2016 offers some core pointers into this process. Throughout April, the populace was carpet-bombed with promotional materials about the civic duty of secret-keeping: pamphlets, cartoons, and animations were distributed in government offices, schools, businesses and housing complexes; lecture programs were launched on media platforms; and mash-up videos were released which used Western media characters such as Batman, Superman, the Joker, Mr Bean, and SpongeBob Squarepants to flag up the insidious dangers of the foreign spy and the risks of treasonous collaboration (figure 5). Perhaps the most striking example, though, came in the form of a cartoon poster 
called Dangerous Love (Weixian de aiqing), which appeared on streets, subways, residential communities, and bulletin boards in Beijing. Over a sequence of 16 narrative panels, the poster traces the tale of a young female cadre in the propaganda bureau, called Xiao Li, who is wooed by a red-headed visiting scholar called David, and inveigled into handing over state secrets (figure 6). David duly absconds with the data, while Xiao Li comes under suspicion of violating state secrecy law.

In one sense, there is nothing much new about Xiao Li and her story of betrayal. Counter-espionage was a frequent-enough theme of propaganda posters and children's linked picture-books (lianhuanhua) during the Maoist era, which often exhorted family members to inform on one another. So it might be argued that the Dangerous Love poster is merely a cosmetic updating of the genre, with sharper colours, a manga-inflected aesthetic, and a racier storyline. But the poster might actually possess a closer spiritual lineage with the "Loose Lips Sink Ships” campaign, deployed in wartime America for the ostensible purpose of thwarting foreign espionage. As some historians have noted, though, the operation may well have been more about what Arendt calls the "organization of the polity" at a time when social cohesion was imperative. Actual spies were dummy (or at best secondary) targets, since the real aim was to "to clamp as tight a lid as possible on rumors that might lead to discouragement, frustration, strikes, or anything that would cut back military production” (Campbell 1984, p. 71). According to statements issued by the Beijing municipal government, the main target of the Dangerous Love campaign was - once again - the cadre class, a tiny number of whom have indeed been honey-trapped over the years. But the positioning of the posters, at eyeline height in the kind of public spaces (subways, streets) more commonly occupied by national-level propaganda (harmonious society, China dream), suggests once again that bureaucrats in the 
security apparatus were only the nominal audience. The true target was the populace, who were being enjoined to take state secrecy seriously by a campaign that coupled the public-space format of the poster with the textbook content-marketing ploy of storytelling.

Yet in a pattern that will soon become familiar, the populace reacted in passive or at best bemused ways to the poster, with netizens on Weibo (China's Twitter-esque platform) lampooning its message as "campy” and "laughable”, ${ }^{19}$ and citizens on the street reacting with a sort of tepid puzzlement. In an article for The New York Times, Didi Kirsten Tatlow straw-polled some members of the Beijing populace about Dangerous Love; the following response was typical:

"How could ordinary people know anything about state secrets?” asked Mr. Liu, a resident of Wudaoying Lane in central Beijing, where one of the posters hangs on the wall of a construction site. "If even young girls know secrets, what kind of secrets are they?” (Tatlow 2016).

Tatlow's piece also features a telling photograph of commuters blanking the poster at Dongdan station on the Beijing subway. Tatlow deduces from these indicators that the campaign "may not be having quite the impact the government hopes", before going on to relate how "A person answering the telephone at the propaganda office of the Beijing municipal party committee requested questions by fax. A fax including a question about the poster went unanswered”. In short, what we see here is a double whammy of disinterest: a population that barely glances at the poster, and a government office which blithely ignores possible espionage leads. Yet rather than signs of dysfunction in the system, as Tatlow argues, these responses actually indicate that Dangerous Love as a piece of thought work played out well and in line with official objectives. As mentioned above, and to paraphrase Mr Liu of Wudaoying Lane, keeping state secrets can only be a perfunctory performance for the vast majority of China's citizens, whose still greater social duty is a kind of willed 
ignorance and passivity about the doings of government. In this sense, a disinterested, even amused reaction - as opposed to either angry resistance or active spycatching signals that the thought work drive is inciting participation in a productively nonparticipatory way.

Five days before the next "National Security Education Day" in 2017, counter-espionage surfaced once more. This time it became a target for a move uncannily akin to crowdsourcing, as the Beijing State Security Bureau issued a notice in the Beijing Daily informing the capital's population that very significant cash rewards (up to 500,000 yuan) could be claimed by those who provided intelligence to the authorities about the doings of foreign spies. Citizens had the choice of calling an informant hotline, mailing intelligence to the "state security organs" in Dongcheng District, or reporting to the offices directly in person (n.a.(a) 2017, p. 3). A statement posted on the Beijing Government website stated that "combining specialist workers with the mass line is a political advantage and important principle in the work of national security, and a vital magic weapon (fabao) in defeating the enemy” (n.a.(b) 2017. But when foreign journalists covering the story went again onto the streets of Beijing to gauge reactions, they mostly encountered bafflement once more, as ordinary citizens wondered where on earth they might procure this kind of red-hot lucrative data. As one passerby put it succinctly: "Everyday citizens really have no idea about such things, such inside stories. That's the sort of thing that comes through the investigations of national security departments and other relevant agencies” (Kopczynski 2017). As if to corroborate the point - and in an echo of the New York Times story - when CNN called the hotline on four separate occasions, no-one picked up, “save for an automatic welcome message” (Kam et al. 2016). The CNN journalists took all this as proof-positive of a xenophobic turn in state propaganda. 
Yet, once again, what is more significant here is the stance of knowing disinterest adopted by both citizens and cadres alike.

Unsurprisingly, this laissez-faire approach to following up on tips contrasts starkly with the official message on how ordinary people, incorporated into a new mass line, should be deployed in the securitizing of the Chinese polity. A cartoon video released in April 2017 by the Beijing State Security Bureau to support the new policy initiative, otherwise known as "Rewards for Citizens who Report Signs of Espionage” (Gongmin jubao jiandie xingwei xiansuo jiangli banfa), states that

Even if you hide, taking cover in the remotest corners of the earth, the Beijing National Security Administration will do its utmost to track you down, wantonly bombarding you with phone calls, and blotting out the sky and covering the earth with public announcements - all with the sole purpose of ensuring that you receive your reward. ${ }^{20}$

On one level, what we see here is content-marketing logic operating at full throttle.

According to standard "CM" discourse, content has value when the customer decides it does, rather than when companies try to decree the fact; and here that process reaches a highwater mark as the state actually offers to pay citizens for the product information - that its own campaign is promoting. But the video simultaneously suggests another, stranger, story. The key sequence quoted above shows silly scenes of an informer being chased by a giant telephone and being deluged by a paper storm of public announcements (figure 7), paired to a voiceover and subtitles littered with grandiose phrases: "remotest corners of the earth" (tianya haijiao), "do its utmost” (buyi yuli), “wantonly bombarding” (kuanghong lanzha), “blot out the sky and cover the earth" (putian gaidi). This generates a sense of mixed messaging between image and word, which is then echoed still more resoundingly in the mismatch between the super-proactive posturing of the Security Bureau and its actual practice of letting informant calls go to voicemail. Like Dangerous Love before it, the video elicits 
interactivity in a disingenuous spirit. Rather than recruiting genuine grass-roots counter-espionage agents, the video uses its info-heavy, soft-soap format to model a more performative mode of participation. At a time when large-scale securitization is the new dogma, and information is transferring from subjects to the state in a unidirectional and mandatory flow, citizenly input takes on darkly farcical hues. Hence the huge telephone that chases.

A further telling example of this kind of "sham" performance occurred over several months during 2016 and 2017, when various organisations collaborated in running a well-publicised comic-drawing competition. The list of bodies which were involved was extensive: the Guangzhou Bureau of State Secrecy, the Guangzhou Municipal Bureau of Justice, the Municipal Propaganda Department, the Municipal Press and Publication Bureau, the State-owned Assets Supervision and Administration Commission, the Municipal Bureau of Education, the Guangzhou Committee of the Communist Youth League, the Guangzhou Broadcasting Network, the Guangzhou Daily Newspaper Group, the Guangdong Artists Association, the Guangzhou Animation and Cartoon Association, and the School of Visual Art and Design at the Guangzhou Academy of Fine Arts. The topic of the contest was “The Law on State Secrets”. Two prizes of 3000 yuan were offered for the best entries, with a range of smaller prizes also up for grabs. The website announced that the core aim of the competition was to "use the comic brush to tell stories about keeping secrets, to use the comic form to interpret knowledge about keeping secrets, and to protect the state secrets that matter to you and me"; and it was targeted at "all of society, with a special focus on government cadres and employees at all levels in the Guangzhou area, high-school and middle-school students, and cartoon enthusiasts”. ${ }^{21}$ 
Guangzhou Reference (Guangzhou cankao), a local state-run media platform, glossed the objectives of the competition in more detail, stating that it sought

... to foster the creation of cartoon and cultural works about keeping secrets, to spark a craze for studying "The Law on State Secrets" so as to ensure that everyone grasps the point that "keeping secrets is no trifling matter, and should be kept firmly in mind", and to enhance the ability of the broad ranks of cadres and the masses to maintain secrecy in accordance with the law (n.a. 2016).

At the time of writing, the Guangzhou Bureau of State Secrecy website displayed 1,485 of the entries, posted on scores of consecutive webpages (figure 8). 102 of the best entries were also included in a touring exhibition, which travelled to public libraries and other venues in Guangdong Province during November 2017, with the aim of "broadly disseminating the winning entries in order to expand the influence of the competition within the broader context of forming a strengthened atmosphere for upholding the rule of law with regard to state secrecy” (n.a.(c) 2017). Local news websites carried numerous images showing bands of visitors absorbing just these lessons as they wandered around the exhibits, listened to presentations about the cartoons and their contributions to successful secret-keeping, and posed for group photographs. In many ways, the competition and its associated exhibition come straight from the content marketing playbook, which often deploys crowdsourcing in the form of idea competitions as a means of accelerating the content creation process, procuring content without cost, growing the target audience, and fostering loyalty by showing how keen the brand is to listen to what its customers think and say. And the fact that the competition was all about getting kids to draw cartoons seems to set the seal on the bigger sell that state secrecy is a force whose intentions, if not quite cuddly, are paternalistically benign - at the same time as showing that the young must 
be inducted early into the imperatives of anti-espionage, intelligence gathering, and keeping mouths closed.

Yet the choice of cartoon art, once again, as the medium for creating this "strengthened atmosphere for upholding the rule of law with regard to state secrecy" also resonates on another, darker register. In recent years, the Chinese state has been repeatedly lampooned by political cartoonists on social media, who make bona fide, lock-and-key state secrets a particular target of their work. Badiucao, the most prolific of these digital dissidents, has satirized the disappearance of human rights activists, China's extensive use of the death penalty, the links between high officials and offshore shell companies, and state policy towards Beijing’s “low-end population”all in his trademark black and red inks, which speak all too volubly of graft, violence, and death. These cartoonists have exasperated the state so intolerably that almost all have been forced first off Weibo and then out of the country. In this sense, the Guangzhou competition is also a populist reappropriation of the political cartoon - for what is state secrecy if not political? - from these exiled malcontents who have deployed the medium to call state secret-keepers to account, and it's a reappropriation that drains all vim and venom from the practice of drawn satire. The cartoons in the Guangzhou competition are superficially mixed in their aesthetic presentation: some are technically quite sophisticated, while others are evidently drawn by schoolchildren on crumpled bits of paper, with the calligraphy probably penned by a parent. Yet the images share two core commonalities. The first is a cutesy visual language, often achieved via recourse to established and non-threatening cartoon characters or tropes (Charlie Brown, doe-eyed manga-inspired figures); and the second is a striking void in terms of content. 
As a body of images, the competition entries do little more than exhort the importance of keeping state secrets, and in a manner almost as syllogistic and emptied of graspable meaning as the phrases in China's constitution. For sure, keeping state secrets means resisting bribes and seductive women (figures 9 and 10), and informing on relatives (figure 11); but it is also about blocking the gap in the wall through which leaks might escape (figure 12); noticing that secrets are escaping from a water bucket (figure 13); and even simply treasuring the Law on State Secrecy in both hands (figure 14). Indeed, many of the cartoons are so substanceless that it is hard to see how they could possibly assist in "forming a strengthened atmosphere for upholding the rule of law with regard to state secrecy”. Rather than the professional act of keeping state secrets, what is incited here instead is the required social performance of accepting life in a cryptocracy - which is to say, modelling citizenship in the newstyle, new-media cryptosphere. In this domain, it is not the content of state secrets which matters, but rather an acted-out acknowledgement that it is only right and proper for the public to know very little about how governance is carried out, for vast swathes of publically pertinent data to remain strictly classified, and for a new regime of biometric profiling and data-driven behavior management to ensure that information will travel only one way. Unlike the political cartoons of Badiucao et al., which are a feast of pun, allusion, and visual ploy, and which often draw blood, the Guangzhou competition entries reiterate a message as consciously and conspicuously vacant as the call to Beijing's citizenry to inform on the foreign spies whom they have never met. The cartoons are participatory propaganda whose message/medium is precisely to have no content, and thus to be intentionally disinformational. Or to recast this in the language of the covert, if secrets expire via the telling - as Derrida argued - then the secret that was never known in the first place waxes stronger the 
more broadly the social myth that it is everyone's duty "to protect state secrets" is disseminated (1989, p. 16-17).

\section{Coda: secrecy as social method}

The propaganda push I have discussed above is still in its early days, even if China's cryptosphere has deep roots. ${ }^{22}$ The signs suggest, though, that secrecy as social method is consolidating itself as a policy priority: the latest National Security Education Day - on April 15 ${ }^{\text {th }}$, 2019 - saw renewed efforts, in the form of further infographics and animated videos, to mobilize the new-media arsenal as a means of promoting spy-catching and secret-keeping as every Chinese person’s public duty. To an extent, moves of this kind recall the Maoist-era "mass line”, the political doctrine which declared that CCP cadres should interact with the masses, learn from their ideas, and develop them into official policy. Indeed, Xi Jinping has signalled clearly since becoming leader his intent to reignite the mass line with all its attendant political fervor. Yet the mass line, as we know from Cultural Revolution history, also harbours within it the seeds of precisely the kind of autonomous eruption of popular will that China's vast and integrated "stability maintenance” (weiwen) apparatus is tasked with tamping down (and whose gargantuan budget is - no surprises here - one of China's most closely-guarded state secrets). The mass line and grassroots rights defense movements are, in that sense, both as apparently distant, and as counterintuitively close, as the numerals " 11 ” and " 1 ” on a clockface. The distance between them simply varies according to the direction of travel.

Given this, it might seem strange that a leadership which dedicates such significant resource to blocking and breaking up group-based political activism would run a series of propaganda campaigns so reminiscent of the mass line and its proactively participatory culture. These campaigns, though, invoke the letter rather 
than the spirit of the original mass line. They do so as part of a larger attempt to breathe selective life into the carcass of Maoism: from wearing Xi Jinping badges to singing "red" songs to hell-for-leather purges of political enemies. Some might argue that reviving these old ways, if only in strategically limited fashion, helps to facilitate a charisma infusion from Mao to Xi. Yet rather than a cult of personality, the propaganda discussed in this paper is about the new ascendancy of a cult of the clandestine, about secrecy as social method. And arguably, it is in this latter sense that recent strategic returns to Maoism play their part. The harking back to a time when all were supposedly mobilized on a revolutionary footing entrenches the message that secrecy is every citizen's urgent political priority: it enhances collectivist rhetoric. The catch, of course, is that this collectivism is toothless, since what is really being sold is a state of knowing ignorance and docility in the face of invasive information management. Indeed, rather than participatory action, this new mass line - in keeping with the Žižekian notion of ideology discussed above - is ultimately, and paradoxically, about the incitement of performative passivity. As with all propaganda pushes, a degree of grass-roots resistance is inevitable, as Repnikova and Fang demonstrate in their analysis of satirical responses to "authoritarian participatory persuasion 2.0”. But resistance to the emerging cryptosphere will be all the harder when, for most of China's people, there are scant national secrets to keep and only private ones to lose.

I am very grateful to Michel Hockx for his insightful comments on an earlier draft of this paper.

${ }^{1}$ I take some of these secrets from the list of seven suggested by bloggers in China in the aftermath of WikiLeaks as archival must-knows should a similar breach of information occur in China. See Perry Link, 2010. 
${ }^{2}$ As Raymond Siu Yeung Chan and John Kong Shan Ho put it, “These laws in general suffer from an overwhelming lack of clarity ... (which) leave open large areas of ambiguity and uncertainty” (2015, p. 99). Mitchell A. Silk and Jillian S. Ashley state in a similar vein that "Despite several updates to laws governing "state secrets" in China over the years, the concept of state secrets remains amorphous and subject to interpretation in line with prevailing political winds" (2011).

${ }^{3}$ For the "Law of the People's Republic of China on Guarding State Secrets", see http://www.gov.cn/flfg/2010-04/30/content_1596420.htm.

${ }^{4}$ See http://www.baomi.org/control/index.

${ }^{5}$ See Rhodan, 2016.

${ }^{6}$ See Battaglia, 2017.

${ }^{7}$ It should be noted, however, that media reporting outside China on the social credit system has often been sensationalist in ascribing exclusively malignant powers to this emergent form of governmentality. For a critique of this commentary, see Daum

2017. Daum rightly observes that building and keeping trust is the central plank of the social credit system; but it is also likely that this system, as it beds in, will incite citizens to police their speech and conduct more vigorously.

${ }^{8}$ China, it should be noted here, is by no means an outlier in terms of surveillance, and London alone had 627, 707 cameras as of 2019 (Ratcliffe 2019). That said, the data harvested by China's cameras can be put to more extensively punitive use, via technologies of facial and so-called "gait" recognition.

${ }^{9}$ See http://www.ohchr.org/EN/HRBodies/CED/Pages/ConventionCED.aspx.

${ }^{10}$ For Victoria’s Secret, see Mason 2017.

${ }^{11}$ For a discussion of specifically televisual representations in the covert sphere, see Kackman, 2005.

12 For more on citizenly participation in homeland security, see Andrejevic 2007, 1645.

${ }^{13}$ See http://aiddata.org/data/chinese-global-official-finance-dataset

${ }^{14}$ For the Chinese constitution, see http://www.npc.gov.cn/wxzl/wxzl/2000-

12/06/content_4421.htm. For China’s Criminal Law, see

http://www.npc.gov.cn/wxzl/gongbao/2000-12/17/content_5004680.htm.

${ }^{15}$ See http://www.gov.cn/zwgk/2014-02/03/content_2579949.htm.

${ }^{16}$ For persuasion, see Brady and Wang, 2009; Zhang, 2016; and Esarey, Stockmann, and Zhang, 2017. For social media as social control in authoritarian environments, see Gunitsky, 2015.

${ }^{17}$ The use of "eyes and ears" was itself, to a limited degree, reminiscent of the baojia system, a mechanism of neighborhood-based policing, self-defense, and social control introduced in the Song dynasty which continued intermittently until the start of CCP rule in 1949.

18 The stand-out example of this is the so-called "grid management" (wanggehua guanli) system that some local governments have begun rolling out as means of monitoring communities. According to this policy, specific individuals are tasked with collecting information on households within a segment or neighbourhood within the "grid".

${ }^{19}$ For some reactions on Weibo, see:

https://s.weibo.com/weibo/\%25E2\%2580\%259C\%25E5\%258D\%25B1\%25E9\%2599 \%25A9\%25E7\%259A\%2584\%25E7\%2588\%25B1\%25E6\%2583\%2585\%25E2\%258 0\%259D\%2520\%25E2\%2580\%259C\%25E6\%25BC\%25AB\%25E7\%2594\%25BB\% 25E2\%2580\%259D?topnav=1\&wvr=6\&b=1.

${ }^{20}$ See http://www.sohu.com/a/133076446_115239. 
${ }^{21}$ See http://gzbm.topcacc.net.

22 There are, for example, evident links between the disciplinary techniques on which the cryptosphere relies and the post-Mao policies of "human improvement" and social control which Borge Bakken memorably summarized as China's "exemplary society" (Bakken 2000).

\section{References}

Andrejevic, M., 2007. iSpy: Surveillance and power in the interactive era. Lawrence: University Press of Kansas.

Anon., 2016. Guangzhou qidong 'Baomifa’ zhuti manhua chuangzuo bisai (Guangzhou launches a cartoon creation competition on the subject of the 'Law on State Secrets'). Guangzhou cankao. Available from:

http://www.gzcankao.com/news/detail?nid=23703 [Accessed 23 November 2017].

Anon., 2017. Gongmin jubao jiandie xingwei xiansuo jiangli banfa (Measures about the rewards available for citizens who report leads on espionage). Beijing ribao (Beijing Daily), April 10, 3.

Anon., 2017. “Gongmin jubao jiandie xingwei xiansuo jiangli banfa” jiedu (An interpretation of 'Measures about the rewards available for citizens who report leads on espionage’). Beijingshi renmin zhengfu (Beijing Municipal People’s Government). Available from:

http://zhengce.beijing.gov.cn/library/192/34/205/898444/158461/index.html [Accessed 10 December 2017].

Anon., 2017. Hei, baomiju qing ni lai kan manhuazhan la! (Hey, the State Secrecy Bureau invites you to a cartoon exhibition!). Guangzhou.gov.cn. Available at: http://www.guangzhou.gov.cn/node_2382/node_536/node_538/201709/1506069946719670.shtml [Accessed 14 September 2017].

Arendt, H., 1973. The origins of totalitarianism. New York: Harcourt Brace Jovanovich.

Bakken, B., 2000. The exemplary society. Human improvement, social control, and the dangers of modernity in China. Oxford: Oxford University Press.

Battaglia, G., 2017. Dear China, I am a white guy and not a spy. South China Morning Post, April 16. Available from: https://www.scmp.com/weekasia/politics/article/2087516/dear-china-i-am-white-guy-and-not-spy [Accessed January 14 2018].

Baudrillard, J., 1999. Revenge of the crystal: selected writings on the modern object and its destiny, 1968-1983, trans. Foss, P. and Pefanis, J. London: Pluto Press.

Birchall, C., 2016. Managing secrecy. International journal of communication 10, 152-63. 
Brady, A-M., 2009. Marketing dictatorship: propaganda and thought work in contemporary China. Lanham: Rowman and Littlefield.

Brady, A-M and Wang Juntao, 2009. China's strengthened new order and the role of propaganda. Journal of Contemporary China 18 (62), 767-788.

Bratich, J.Z., 2007. Popular secrecy and occultural studies. Cultural studies, 21 (1), 42-58.

Bratich, J.Z., 2014. Adventures in the public secret sphere: Police sovereign networks and communications warfare. Cultural studies, 14 (1), 11-20.

Campbell, D’A., 1984. Women at war with America: private lives in a patriotic era. Cambridge, MA: Harvard University Press.

Caster, M., ed., 2017. The people's republic of the disappeared: stories from inside China's system for enforced disappearance. Place of publication not identified: Safeguard Defenders.

Central People's Government of the Republic of China, 1988. Zhonghua Renmin Gongheguo baoshou guojia mimifa (Law of the People's Republic of China on Guarding State Secrets). Available from: http://www.npc.gov.cn/wxzl/wxzl/200012/10/content_4509.htm [Accessed 20 October 2017].

Central People's Government of the Republic of China, 1990. Zhonghua Renmin Gongheguo baoshou guojia mimifa shishi banfa (Measures for implementing the law of the People's Republic of China on guarding state secrets). Available from:

https://baike.baidu.com/item/中华人民共和国保守国家秘密法实施办法 [Accessed 12 December 2017].

Central People's Government of the Republic of China, 2010. Zhonghua Renmin Gongheguo baoshou guojia mimifa (Law of the People's Republic of China on guarding state secrets). Available from:

http://www.gov.cn/flfg/2010-04/30/content_1596420.htm [Accessed 15 December 2017].

Central People's Government of the Republic of China, 2014. Guojia mimi dingmi guanli zanxing guiding (Interim Provisions on the Management of State Secrets) (2014) Available from: http://www.gov.cn/gongbao/content/2014/content_2671533.htm [Accessed 25 July 2017].

Central People's Government of the Republic of China, 2014. Zhonghua Renmin Gongheguo baomi guojia mimifa shishi tiaoli (Regulations on the implementation of the law of the People's Republic of China on guarding state secrets). Available from: http://www.gov.cn/zwgk/2014-02/03/content_2579949.htm [Accessed 9 Novemebr 2017].

Chan, R.S.Y. and Ho, J.K.S., 2015. Could complying with China's secrecy laws be an excuse for auditors not to provide their working papers of auditing Chinese 
companies? Recent cases in the United States and Hong Kong. King's law journal, 6 (1), 99-128.

Daum, Jeremy. 2017. China through a glass, darkly. What foreign media misses in China's social credit. China law translate. Available from:

https://www.chinalawtranslate.com/seeing-chinese-social-credit-through-a-glassdarkly/?lang=en [Accessed June 17, 2018].

Debord, G., 1998. Comments on the society of the spectacle, trans. Imrie, M. London: Verso.

Derrida, J., 1989. How to avoid speaking: denials. In: S. Budick and W. Iser, eds. Languages of the unsayable: the play of negativity in literature and literary theory. New York: Columbia University Press, 3-70.

Esarey, A., Stockmann, D., and Zhang, J., 2017. Support for propaganda: Chinese perceptions of public service advertising. Journal of contemporary China, 26 (103), 101-117.

Finder, S., 2014. How China classifies state secrets. The Diplomat, December 23. Available from: http://thediplomat.com/2014/12/how-china-classifies-state-secrets/ [Accessed 17 July 2017].

Gunitsky, S., 2015. Corrupting the cyber-commons: Social media as a tool of autocratic stability. Perspectives on politics, 13 (1), 42-54.

Hay, J. and Andrejevic, M., 2006. Introduction. Cultural studies, 20 (4-5), 331-348.

Human Rights in China, 2013. State secrets: China's legal labyrinth. New York: HRIC. Available from:

http://www.hrichina.org/sites/default/files/publication_pdfs/hric_statesecretsreport.pdf [Accessed 5 January 2018].

Kackman, M., 2005. Citizen spy: Television, espionage, and Cold War culture. Minneapolis: Minnesota University Press.

Kam, V., Kook, A., and McCafferty, G., 2016. The spy who loved me? Chinese warned off dating foreigners. CNN, April 21. Available from:

http://edition.cnn.com/2016/04/21/asia/china-foreign-spies/index.html [Accessed 30 December 2017].

Kopczynski, B., 2017. China offers big rewards for tips on foreign spies. VOA News, April 13. Available from: https://www.voanews.com/a/china-offers-big-rewards-fortips-on-foreign-spies/3808658.html [Accessed 28 September 2017].

Link, P., 2010. Waiting for WikiLeaks: Beijing’s seven secrets. New York Times, August 19. Available from: http://www.nybooks.com/daily/2010/08/19/waitingwikileaks-beijings-seven-secrets/ [Accessed 15 March 2017]. 
Masco, J., 2010. "Sensitive but unclassified": Secrecy and the counterterrorist state. Public Culture, 22 (3), 433-463.

Mason, Paul. 2017. How China made Victoria's Secret a pawn in its ruthless global game. The Guardian, November 20. Available from:

https://www.theguardian.com/commentisfree/2017/nov/20/victorias-secret-chinacensorship-lingerie-gigi-hadid-gaffe-repressive-state [Accessed June 1, 2019].

Melley, T., 2012. The covert sphere: Secrecy, fiction, and the national security state. Ithaca: Cornell University Press.

National People’s Congress, 1982. Zhonghua Renmin Gongheguo xianfa (Constitution of the People's Republic of China). Available from:

http://www.npc.gov.cn/wxzl/wxzl/2000-12/06/content_4421.htm [Accessed 26

September 2017].

National People’s Congress, 1997. Zhonghua Renmin Gongheguo xingfa (Criminal law of the People's Republic of China). Available from:

http://www.npc.gov.cn/wxzl/gongbao/2000-12/17/content_5004680.htm [Accessed 2 September 2017].

Nuttall, S. and Mbembe, A., 2015. Secrecy's softwares. Current anthropology, 56 (12), 317-324.

Pulizzi, J., 2012. The rise of storytelling as the new marketing. Publishing Research Quarterly, 28, 116-23.

Ratcliffe, Jonathan. 2019. How many CCTV Cameras are there in London 2019? CCTV.co.uk, May 29. Available from: https://www.cctv.co.uk/how-many-cctvcameras-are-there-in-london/ [Accessed May 15, 2019].

Repnikova, M., and Fang, K., 2018. Authoritarian participatory persuasion 2.0: netizens as thought work collaborators in China. Journal of contemporary China, 27 (113), 763-779.

Rhodan, M., 2016. China warns against falling in love with foreigners in new poster. Time, April 22. Available from: http://time.com/4304572/china-warns-against-fallingin-love-with-foreigners-in-new-poster/ [Accessed 5 June 2019].

Schoenhals, M., 2013. Spying for the people: Mao’s secret agents, 1949-1967. Cambridge: Cambridge University Press.

Silk, M.A. and Ashley, J.S., 2011. Understanding China's state secrets laws. China business review, January 1. Available from: http://www.chinabusinessreview.com/understanding-chinas-state-secrets-laws/ [Accessed 22 August 2017]. 
Tatlow, D.K. 2016. China's 'Dangerous Love' campaign, warning of spies, is met with shrugs, April 21. Available from:

https://www.nytimes.com/2016/04/22/world/asia/china-foreign-spy-warning.html [Accessed 1 June 2018].

United Nations' Committee on Enforced Disappearances, 2010. International convention for the protection of all persons from enforced disappearance. Available from: http://www.ohchr.org/Documents/ProfessionalInterest/disappearanceconvention.pdf [Accessed 22 November 2017].

Zhang T., 2016. Wangluo yulun shengtai de zhili celüe (Governance strategies for online public opinion), Xinwen yu xiezuo (News and writing), 7, 22-25.

Žižek, S., 1994. How did Marx invent the symptom? In: S. Žižek, ed. Mapping Ideology. London: Verso, 296-331.

Žižek, S., 2011. Good manners in the age of WikiLeaks. London Review of Books, 20 January. Available from: https://www.lrb.co.uk/v33/n02/slavoj-zizek/good-mannersin-the-age-of-wikileaks [Accessed 20 December 2017]. 